\title{
Knowledge, Attitude and Practice of Menstrual Hygiene among High Schools Students in Jatinangor
}

\author{
Maryam Balqis, ${ }^{1}$ Insi Farisa Desy Arya, ${ }^{2}$ Mulya Nusa A Ritonga ${ }^{3}$ \\ ${ }^{1}$ Faculty of Medicine Universitas Padjadjaran, ${ }^{2}$ Department of Public Health Faculty of Medicine \\ Universitas Padjadjaran, ${ }^{3}$ Department of Obstetric \& Gynecology Faculty of Medicine Universitas \\ Padjadjaran/Dr. Hasan Sadikin General Hospital, Bandung
}

\section{Abstract}

Background: Menstruation is a physiological process in female adolescents which usually started at age of 9-12 years. Menstrual hygiene is a hygienic practice during menstruation which can prevent women from the infection in reproductive and urinary tract. Lack of knowledge regarding menstruation and menstrual hygiene lead to poor attitude and practice. This study was conducted to assess the level of knowledge, attitude and practice of menstrual hygiene among high schools students in Jatinangor.

Methods: This descriptive cross-sectional study was conducted from May until June 2013 in high schools around Jatinangor. This study population was taken from four schools selected through cluster random sampling from 17 junior and senior high schools available in Jatinangor. Total sampling from four schools was undertaken and a total of 238 female high school students' data were established. The respondents aged between 13-19 years old.

Results: The level of knowledge, attitude and practice among participants were 180 (75.63\%), 186 (78.15\%) and $210(88.24 \%)$ respectively which were mostly good.

Conclusions: Overall, most of the participants in this study have good knowledge, attitude and practice about menstrual hygiene, but a few of them still have poor and moderate knowledge and attitude, although there is no poor practice among them. [AMJ.2016;3(2):230-8]

Keywords: Adolescent, knowledge, menstrual hygiene, practices

\section{Introduction}

Menstruation is a physiological process in female adolescent which usually started at age of 9-12 years old. ${ }^{1}$ First menstruation experience would be different among adolescent girl but if they aware about menstruation before menarche, they can prepare themselves to accept and build good attitude towards menstruation. Mother as the nearest and capable person to educate their children should give information about menstruation and also hygiene prior to menarche so that adolescent girls know the importance of taking care of hygiene during menstruation and how to manage menstrual hygiene issues.

Menstrual hygiene is a hygienic practice during menstruation and good menstrual hygiene such as adequate cleaning of the external genitalia, the use of sanitary pad and frequently changed pad every 3-4 hours to prevent odor. ${ }^{2}$ Unhygienic practices during menstruation predispose to higher chances to get infection or gynecological problems among adolescent girls. ${ }^{3}$ The prevalence of reproductive tract infections are 3 times higher among girls who have poor menstrual hygiene. ${ }^{4}$ Therefore, hygiene related to practices during menstruation considered as important to decrease the risk of infection among female. However, in a way to achieve safe practices, they need a satisfactory knowledge about menstruation and menstrual hygiene; women having good knowledge and practices regarding menstrual hygiene are less exposed to RTI and its consequences. ${ }^{5}$

Besides that, there are factors that affects the person's hygiene such as socioeconomic status that influenced person's ability to regularly maintain hygiene, health beliefs and motivation about importance of hygiene, and cultural behavior which depends on person's cultural belief and personal values

Correspondence: Maryam Balqis, Faculty of Medicine, Universitas Padjadjaran, Jalan Raya Bandung-Sumedang Km.21, Jatinangor, Sumedang, Indonesia, Phone: +62 81809832502 Email: miss_alamandas@yahoo.com 
hygiene care. ${ }^{6}$ Having knowledge regarding to menstruation and menstrual hygiene does not guarantee that the girls have good attitude and practice toward menstrual hygiene because they need to motivate themselves to maintain self-care. So, this study was conducted to assess the level of knowledge, attitude and practice of menstrual hygiene among high school students in Jatinangor.

\section{Methods}

This descriptive cross-sectional study was conducted from May until June 2013 in high schools around Jatinangor. The data were taken under the permission of Faculty of Medicine Universitas Padjadjaran research programme named "Jatinangor Cohort". There are several studies conducted under Jatinangor Cohort. The conducted study such as puberty in female and male, nutritional status in school students, menarche, dysmenorrhea, menstrual hygiene and other topics were included.

Jatinangor Cohort involved large population study including elementary school students, junior high school students, senior high school students and others but in this study, the study population was taken from four schools selected through cluster random sampling from 17 junior and senior high schools available in Jatinangor by Jatinangor Cohort. Total sampling from four schools was done and a total of 238 female high school students' data was established. The respondents age were between 13-19 years old.

The inclusion criteria were female students who had menarche and regularly menstruate whereas the exclusion criteria were respondents whom the data were incomplete.

Questionnaires were distributed to the study subjects in Indonesian language. The questionnaire consists of demographic characteristics, knowledge of menstruation and hygiene, attitude and practice towards menstrual hygiene. The demographic data consist of five questions, five questions for knowledge, nine questions for attitude and nine questions for practice respectively to each variable. These questionnaires had been validated by Jatinangor Cohort. The data were taken from Jatinangor Cohort as the secondary data and the data were analyzed.

The scales to measure the knowledge according to Nursalam $^{7}$ where the level of knowledge considered as good when total score is $76-100 \%$, moderate when the score is $56-75 \%$ and poor when it is $<56 \%$. whereas for attitude and practice were measured according to Arikunto. ${ }^{8}$ For this study, the attitude contains 9 questions, then multiplied by 4 which the highest score for each of attitude, so that the total scores were 36 marks. Then, 36 was divided by 3 categories which is good when total scores is 25-36 marks, moderate when 13-24 marks, poor when $\leq 12$ marks. $^{8}$ Same calculation was used for practice. Then the result was presented in tables.

\section{Results}

The majority of study subjects' age were 16 years old $102(42.86 \%)$ and about $3(1.26 \%)$ of the participants still do not have toilet facilities at home. Furthermore, most of the girls were the first child in the family and do not have sisters who live together. Meanwhile, the table shows the main source of knowledge regarding menstruation and menstrual hygiene came from their mothers as well as friends and teacher. For the source of information about menstruation, the participants were allowed to answer more than 1 the source of their knowledge (Table 1).

All of the participants knew that menstruation was a normal process for women but about $19.33 \%$ of them do not know that menstruation occurs because of hormone. However, $32.77 \%$ of the girls answered that they do not know the source of blood during menstruation. Despite so, 8 of participants do not know that taking care of personal hygiene is important things and $1.68 \%$ still do not know which good absorbent should be used during menstruation and $5.88 \%$ stated that old cloths or towels were good absorbent (Table 2).

Table 3 showed that the attitute toward menstrual hygiene was quite good. Most of the girls were agree that taking care of personal hygiene during menstrual periode can prevent disease. Taking care personal hygiene including using soap and water when cleaning genital body and washing panties and also using panties made from cotton material to absorb sweat (Table 3 ).

Most of the respondents performed menstrual practice hygiene (Table 4).

The level of knowledge, attitude, and practice among participants were divided into 3 categories:poor, moderate and good. After that the results depict most of the participants knowledge, attitude and practice were good in $180(75.63 \%), 186(78.15 \%)$ and 210 $(88.24 \%)$ respectively (Figure 1). 
Table 1 Demographic Characteristic of the Study Subjects

\begin{tabular}{|c|c|}
\hline Characteristics & $\mathrm{N}=\mathbf{2 3 8}(\%)$ \\
\hline \multicolumn{2}{|l|}{ Age (years old) } \\
\hline 13 & $6(2.52)$ \\
\hline 14 & $34(14.29)$ \\
\hline 15 & $37(15.55)$ \\
\hline 16 & $102(42.86)$ \\
\hline 17 & $56(23.53)$ \\
\hline 18 & $2(0.84)$ \\
\hline 19 & $1(0.42)$ \\
\hline \multicolumn{2}{|l|}{ Toilet facilities at home } \\
\hline Yes & $235(98.7)$ \\
\hline No & $3(1.26)$ \\
\hline \multicolumn{2}{|l|}{ Position in siblings } \\
\hline 1 & $106(44.54)$ \\
\hline 2 & $69(28.99)$ \\
\hline 3 & $33(13.87)$ \\
\hline 4 & $17(7.14)$ \\
\hline 5 & $7(2.94)$ \\
\hline 6 & $4(1.68)$ \\
\hline 7 & $2(0.84)$ \\
\hline \multicolumn{2}{|l|}{ Number of sisters who live together } \\
\hline 0 & $164(68.91)$ \\
\hline 1 & $62(26.05)$ \\
\hline 2 & $9(3.78)$ \\
\hline 3 & $0(0.00)$ \\
\hline 4 & $2(0.84)$ \\
\hline 5 & $1(0.42)$ \\
\hline \multicolumn{2}{|c|}{ Source of information about menstruation } \\
\hline Mother & $222(93.28)$ \\
\hline Father & $6(2.52)$ \\
\hline Sister & $54(22.69)$ \\
\hline Teachers & $87(36.55)$ \\
\hline Friends & $95(39.92)$ \\
\hline Television/Radio & $27(11.34)$ \\
\hline Newspaper/Magazine & $18(7.56)$ \\
\hline Others & $19(7.98)$ \\
\hline
\end{tabular}

\section{Discussions}

Hygienic practices during menstruation is an important action which needs to be done because start from the first menstruation (menarche) until ceasing of menstruation (menopause), throughout the women's life, menstruation event continuously comes and 
Table 2 Knowledge of Menstruation and Hygiene

\begin{tabular}{lc}
\hline \multicolumn{1}{c}{ Knowledge } & $\mathbf{N = 2 3 8 ( \% )}$ \\
\hline Menstruation is a normal process for women & $238(100.00)$ \\
Yes & $0(0.00)$ \\
No & $0(0.00)$ \\
Do not know & \\
Cause of menstruation & $2(0.84)$ \\
Disease & $188(78.99)$ \\
Hormone & $1(0.42)$ \\
Past sins & $0(0.00)$ \\
Curse & $46(19.33)$ \\
Do not know & \\
Origin of blood & $41(17.23)$ \\
Ovary & $60(25.21)$ \\
Uterus & $59(24.79)$ \\
Vagina & $78(32.77)$ \\
Do not know & \\
Important to take care of personal hygiene & $230(96.64)$ \\
Yes & $0(0.00)$ \\
No & $8(3.36)$ \\
Do not know & \\
Good absorbent during menstruation & $220(92.44)$ \\
Sanitary Pad & $14(5.88)$ \\
Old cloths/towels & $4(1.68)$ \\
Do not know & \\
\hline
\end{tabular}

goes approximately 3-7 days every month. Based on this women cycle, by ignoring the practices during this period will affect their health and thus increase susceptibility to infection of their reproductive and urinary organ. In a study conducted by Dasgupta and Sarkar', about half of the respondents did not have a covered toilet, which causes the limitation for participants to change pad regularly, cleaning genital, washing underwear and pad as well as bathing during menstruation. However in this present study, there are different findings which is about 236 $(99.16 \%)$ out of 238 total participants were having toilet facility at home which make them easier to have hygienic practices. Another study by Thakre et al. ${ }^{10}, 335(86.56 \%)$ have toilet facility at home and $52(13.43 \%)$ does not have the facility in their home.

The main source of knowledge regarding menstruation and menstrual hygiene among respondents in this study was the mother 222 (93.28\%), followed by friends 95 (39.92\%) and teachers 87 (36.55\%). This result might be caused by the good literacy of the mother, and proper relationship between respondents and their mother. In study conducted by Thakre et al. ${ }^{10}$, it is similarly found the majority of the respondents stated that mother $102(71.33 \%)$ was the source of their knowledge but differently followed by sisters $34(23.78 \%)$ and then friends $26(18.18 \%)$. The difference between Thakre et al. ${ }^{10}$ study and this present study is due to the most of the respondents in this study, 106 (44.54\%) are the first child in the family, so that their friends become the source of knowledge after their mother. Meanwhile, according to Juyal et al. ${ }^{11}$, mostly friends $93(31.8 \%)$ were the first source of information then followed by mother $91(31.2 \%)$ and sisters 82 (28.1\%).

Furthermore, it was observed in this 
Table 3 Attitude towards Menstrual Hygiene ( $=238$ )

\begin{tabular}{|c|c|c|c|c|}
\hline Attitude & $\begin{array}{c}\text { Strongly agree } \\
n(\%)\end{array}$ & $\begin{array}{l}\text { Agree } \\
\mathbf{n}(\%)\end{array}$ & $\begin{array}{c}\text { Disagree } \\
\mathbf{n}(\%)\end{array}$ & $\begin{array}{c}\text { Strongly disagree } \\
\mathbf{n}(\%) \\
\end{array}$ \\
\hline $\begin{array}{l}\text { Do not take care of hygiene } \\
\text { during menstruation can cause } \\
\text { disease }\end{array}$ & $132(55.46)$ & $93(39.08)$ & $9(3.78)$ & $4(1.68)$ \\
\hline $\begin{array}{l}\text { Access to clean water and used } \\
\text { of soap for cleaning genital are } \\
\text { important to keep genital in } \\
\text { clean condition }\end{array}$ & $83(34.87)$ & $135(56.72)$ & $19(7.98)$ & $1(0.42)$ \\
\hline $\begin{array}{l}\text { Panties which made of cotton } \\
\text { is the best material to absorb } \\
\text { sweat }\end{array}$ & $44(18.49)$ & $134(56.30)$ & $56(23.53)$ & $4(1.68)$ \\
\hline $\begin{array}{l}\text { Need to dry genital with towel } \\
\text { to keep genital area in dry } \\
\text { condition after bathing/urinate }\end{array}$ & $96(40.34)$ & $117(49.16)$ & $23(9.66)$ & $2(0.84)$ \\
\hline $\begin{array}{l}\text { Washing hand before cleaning } \\
\text { genital area can prevent } \\
\text { reproductive infection }\end{array}$ & $85(35.71)$ & $134(56.30)$ & $18(7.56)$ & $1(0.42)$ \\
\hline $\begin{array}{l}\text { Washing hand after cleaning } \\
\text { genital area can prevent } \\
\text { reproductive infection }\end{array}$ & $61(25.63)$ & 138(57.98) & $31(13.03)$ & $8(3.36)$ \\
\hline $\begin{array}{l}\text { Menstruation occurs because of } \\
\text { disease }\end{array}$ & $0(0.00)$ & $7(2.94)$ & $144(60.50)$ & $87(36.55)$ \\
\hline $\begin{array}{l}\text { Cleaning panties using only } \\
\text { water is enough as the blood } \\
\text { disappear }\end{array}$ & $8(3.36)$ & $19(7.98)$ & $135(56.72)$ & $76(31.93)$ \\
\hline $\begin{array}{l}\text { Drying the panties inside room } \\
\text { is enough as the panties dry }\end{array}$ & $4(1.68)$ & $53(22.27)$ & $137(57.56)$ & $44(18.49)$ \\
\hline
\end{tabular}

present study that all respondents 238 $(100.00 \%)$ believed that menstruation is a physiological process whereas in a study conducted by Sudeshna and Aparajita ${ }^{4}, 87 \%$ of study subjects believed that menstruation is part of physiological process. Even though the study showed the large percentage of girls answered correctly, the remaining 13\% of girls do not believe the statement. In another study conducted in India ${ }^{5}$, about 50 (16.6\%) of the respondents believed that menstruation occur because of curse from God. Meanwhile in this present study there is no respondent who believe to statement. The differences may be due to the lack of knowledge of the participants, mother and less exposure to mass media but vice versa in the present study.

In the present study, it is revealed the large number of respondents, 188 (78.99\%) knew that the cause of menstruation was hormone and $46(19.33 \%)$ answer that they did not know. Meanwhile nearly similar finding was reported in other study carried out by Sudeshna and Aparajita ${ }^{4}, 114$ (60\%) answered hormone as the cause of menstruation and 64 (34\%) did not know. This study stated only $60(25.21 \%)$ of the girls answered correctly that uterus was the source of blood during menstruation while $78(32.77 \%)$ did not know. Almost similiar to Kamath et al. ${ }^{12}$ study, 103 (20.5\%) knew the source of menstrual blood and $201(36.6 \%)$ did not know. But in another study, $219(43.5 \%)$ knew uterus as the source of blood. ${ }^{13}$

In the present study, it is presented that most of the study subjects 220 (92.44\%) knew that the most appropriate absorbent should be used during menstruation was sanitary pad. Only a few of them $14(5.88 \%)$ preferred to use old cloths/towels rather than sanitary pad. This may be due to the location of this study in Jatinangor. Jatinangor is more likely urban area because this area have universities, big central markets, so many small shops near the neighborhood, and higher population density especially students. Therefore, this might be easier for adolescent girls to buy sanitary pad because it is usually more available in 
Table 4 Practice of Menstrual Hygiene

\begin{tabular}{|c|c|}
\hline Practice & $\mathrm{N}=238(\%)$ \\
\hline \multicolumn{2}{|l|}{ Taking bath during menstruation } \\
\hline Using only water & $1(0.42)$ \\
\hline Using water and soap & $237(99.58)$ \\
\hline No bathing & $0(0.00)$ \\
\hline \multicolumn{2}{|l|}{ Wash hand before cleaning genital } \\
\hline Yes & 223(93.70) \\
\hline No & $15(6.30)$ \\
\hline \multicolumn{2}{|c|}{ Cleaning genital after urinate/defecate } \\
\hline Yes & $235(98.74)$ \\
\hline No & $3(1.26)$ \\
\hline \multicolumn{2}{|l|}{ Cleaning genital before changing pad } \\
\hline Yes & $225(94.54)$ \\
\hline No & $13(5.46)$ \\
\hline \multicolumn{2}{|l|}{ Clean genital using } \\
\hline Only water & $123(51.68)$ \\
\hline Water and soap & $114(47.90)$ \\
\hline Only tissue & $1(0.42)$ \\
\hline \multicolumn{2}{|l|}{ Changing pad at school } \\
\hline Yes & $40(16.81)$ \\
\hline No & 198(83.19) \\
\hline \multicolumn{2}{|l|}{ Changing pad per day } \\
\hline 1 time & $11(4.62)$ \\
\hline 2 times & $88(36.97)$ \\
\hline 3 times & $122(51.26)$ \\
\hline$>3$ times & $16(6.27)$ \\
\hline Do not change & $1(0.42)$ \\
\hline \multicolumn{2}{|l|}{ Place of drying panties } \\
\hline Inside the room & $2(0.84)$ \\
\hline Inside the bathroom & $36(15.13)$ \\
\hline Under sunlight & $200(84.03)$ \\
\hline \multicolumn{2}{|l|}{ Wash panties using } \\
\hline Water only & $4(1.68)$ \\
\hline Water and soap & $234(98.32)$ \\
\hline
\end{tabular}

these markets and small shops. Besides, the participants in this study might not came from low socioeconomic status of the family which couldafford to buy and understood the importance of sanitary pad for their reproductive health from the advertisement or from other sources. Meanwhile, it is found in other study that about $145(44.1 \%)$ which not attain half of the total population, chose sanitary pad as their menstrual absorbent. ${ }^{3}$ Mudey et al. ${ }^{14}$ stated that most of respondents $111(37.00 \%)$ reused old cloths as menstrual 


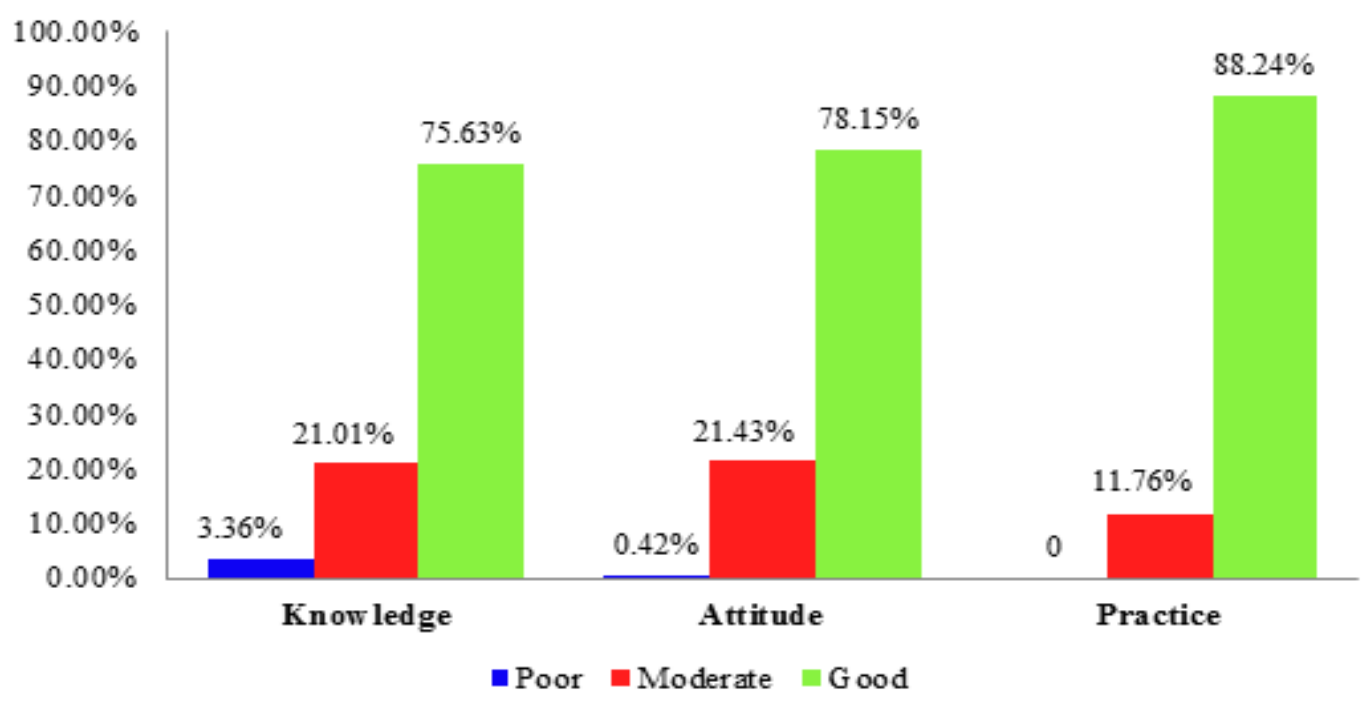

Figure 1 Level of Knowledge, Attitude and Practice of Menstrual Hygiene

absorbents; they prone to develop vaginal discharge, itching and burning micturition as symptoms of infection.

Furthermore, this study found most of the respondents 132 (55.46\%) strongly agree that do not take care of hygiene during menstruation can cause disease. Different findings in other study comparing urban and rural area are revealed. In urban area $56(18.98 \%)$ and rural area 52 (18.06) they believed that menstrual hygiene have effect on reproductive life of girl. ${ }^{15}$ This may be due to lack of knowledge of respondents about the importance of hygiene to their reproductive organ. However, most of the respondents 135 (56.72\%) in this present study agree to the statement that access to clean water and the use of soap for cleaning genital are important to keep genital in clean condition. The researcher expected more respondents to answered strongly agree with the statement. However only 83 (34.87\%) strongly agree, a few of respondents disagree $19(7.98 \%)$ and strongly disagree $1(0.42 \%)$.

Nearly all of the girls have good personal hygiene. Approximately 237 (99.58\%) take bath daily during menstruation using water and soap. This is may be because the majority residents in Jatinangor are Muslims and this religion wanted Muslims to take care of their personal hygiene especially before going prayer but even though during menstruation they are restricted to perform prayer, they are still required to take care of their hygiene. In Omidvar and Begum ${ }^{2}$ study was found, the number of girls do not taking bath during menstruation about 55 (16.1\%). In another study, comparing bathing practice during menstruation between urban and rural area revealed that more respondents in rural area $83(34.7 \%)$ taking bath on alternate day compared to urban area $53(24.8 \%)^{16}$

About 235 (98.74\%) clean their genital every time after urinate or defecate among participants in this study. However, in Omidvar and Begum ${ }^{2}$ study, the percentage was lesser than present study which around $290(82.9 \%)$. Most of the girls 123 (51.68\%) in this study clean their genital using water only without soap but about another half of them $114(47.90 \%)$ using water and soap for cleaning purpose. Otherwise in Thakre et al. ${ }^{10}$ study, revealed that the girls 225 (58.18\%) using water and soap and 157 (40.57\%) using only water as material used for cleaning their external genitalia. In another study, it is stated that $17(11.3 \%)$ clean their genital using soap and water and the rest about 133 (88.7\%) using plain water only. ${ }^{17}$

The study subjects in present study mostly 198 (83.19\%) do not change pad at school and similar result was found in the Omidvar and Begum $^{2}$ and Thakre et al. ${ }^{10}$ study. This could be because of lack of toilet facilities in school, lack of access to clean water and lack of appropriate bin to dispose pad in school. All of these conditions might prevent or inhibit them to change pad during school time. In this study, it is also presented that most of the 
respondents $122(51.26 \%)$ change pad 3 times a day as well as $88(36.97 \%)$ change 2 times a day. This variation of regularly change pad may depend on the respondents' type of pad used, amount of blood comes out and attitude of respondent to remain clean and hygienic. In other study carried out in Mumbai observed that $68(40.96 \%)$ of the girls who use sanitary pad, change pad 2 times a day. ${ }^{18}$

Mostly the level of knowledge, attitude and practice among study subjects were good. This result describes that they have good knowledge, attitude and also practice. This might be because they livein urban area which often expose to the media, frequently along with the educated people, and averagely came from stable socioeconomic status family.

This study has limitation of time, number of respondents and no statistical analysis. Due to limited of time given by Faculty of Medicine Universitas Padjadjaran, and school regulation; certain classes of the students that cannot be disturbed during school learning time, so that the number of respondens are less. For further study, the next researcher can do the research in a longer time and great number of respondents with the statistical analysis for each result. This statistical analysis may be useful to observe the correlation between each variable.

Besides that, the next researcher can ask about type of pad used by the respondents because the good quality of pad can prevent bad odour and itching, thus it can be used longer than the cheaper one. Furthermore, the next researcher can ask about the quantity of blood comes out because some people may have irregularity in menstruation; those who menstruate with not so much blood tend to ignore changing pad regularly.

In conclusion, most of the participants in this study have good knowledge, attitude and practice towards menstrual hygiene, but a few of them still have poor and moderate knowledge and attitude, although there is no poor practice among them. However, awareness concerning the need for knowledge on hygienic menstrual practices is very important to increase their knowledge about the importance of genital cleanliness also, designing a mechanism to help students to improve their hygienic practices especially during menstruation.

Early awareness can prevent students from suffering the infection to the female reproductive organ. This can be achieved through a health programme about the importance of hygienic practice during menstruation to the school girls and it will be more effective if public health department can conduct a programme to educate mother to enhance their knowledge about menstruation, menstrual hygiene and personal hygiene so that they can educate their daughter prior to menstruation or their practice. In other way, teachers may benefits the readily available programme in school called School Health Efforts Society. Teachers can educate and train the members of the society, meanwhile the student leader later may ask the group to help other students. For the stakeholder in school, it is necessary for them to fix or improve the availability of the toilet facilities so it becomes more comfortable and easier for students to regularly change pad even though during school time.

\section{References}

1. Hall JE. Guyton and Hall textbook of medical physiology. 12th ed. Philadephia: Saunders Elsevier; 2010.

2. Omidvar S, Begum K. Factors influencing hygienic practices during menses among girls from south India-A cross sectional study. International Journal of Collaborative Research on Internal Medicine \& Public Health. 2010;2(12):411-23.

3. Shanbhag D, Shilpa R, D'Souza N, Josephine P, Singh J, Goud B. Perceptions regarding menstruation and Practices during menstrual cycles among high school going adolescent girls in resource limited settings around Bangalore city, Karnataka, India. International Journal of Collaborative Research on Internal Medicine \& Public Health. 2012;4(7):1353-62.

4. Sudeshna R, Aparajita D. Determinants of menstrual hygiene among adolescent girls: a multivariate analysis. National Journal of Community Medicine. 2012;3(2):294301.

5. Kamaljit K, Arora B, Singh GK, Neki N. Social beliefs and practices associated with menstrual hygiene among adolescent girls of Amritsar, Punjab, India. JIMSA. 2012;25(2):69-70.

6. Clement I. Textbook of nursing foundations. New Delhi, India: Jaypee Brothers Medical Publishers; 2011.

7. Nursalam. Konsep dan penerapan metodologi penelitian ilmu keperawatan. Jakarta: Salemba Medika; 2008.

8. Arikunto S. Manajemen penelitian. Jakarta: Rineka Cipta; 2007.

9. Dasgupta A, Sarkar M. Menstrual hygiene: 
how hygienic is the adolescent girl?. Indian J Community Med. 2008;33(2):77-80.

10. Thakre SB, Thakre SS, Reddy M, Rathi N, Pathak K, Ughade S. Menstrual hygiene: knowledge and practice among adolescent school girls of Saoner, Nagpur District. Journal of Clinical and Diagnostic Research. 2011;5(5):1027-33.

11. Juyal R, Kandpal S, Semwal J, Negi K. Practices of menstrual hygiene among adolescent girls in a District of Uttarakhand. Indian Journal of Community Health. 2012;24(2):124-8.

12. Kamath R, Ghosh D, Lena A, Chandrasekaran V. A study on knowledge and practices regarding menstrual hygiene among rural and urban adolescent girls in Udupi Taluk, Manipal, India. Global Journal of Medicine and Public Health. 2013;2(4):1-9.

13. Singh S, Singh M, Arora M, Sen P. Knowledge assessment regarding puberty and menstruation among school adolescent girls of district Varanasi. Indian J Prev Soc Med. 2006;37(1\&2):9-14.

14. Mudey AB, Kesharwani N, Mudey GA, Goyal
RC. A cross-sectional study on awareness regarding safe and hygienic practices amongst school going adolescent girls in rural area of Wardha District, India. Global Journal of Health Science. 2010;2(2):22531.

15. Patle R, Kubde S. Comparative study on menstrual hygiene in rural and urban adolescent girls. Int J Med Sci Public Health. 2014;3(1):111-4.

16. Juyal R, Kandpal S, Semwal J. Social aspects of menstruation related practices in adolescent girls of district Dehradun. Indian Journal of Community Health. 2013;25(3):213-6.

17. Adhikari P, Kadel B, Dhungel S, Mandal A. Knowledge and practice regarding menstrual hygiene in rural adolescent girls of Nepal. Kathmandu University Medical Journal. 2007;5(19):382-6.

18. Nemade D, Anjenaya S, Gujar R. Impact of health education on knowledge and practices about menstruation among adolescent school girls of Kalamboli, NaviMumbai. HPPI. 2009;32(4):167-75 